\title{
KAJIAN DISTRIBUSI SEDIMENTASI WADUK BENING KABUPATEN MADIUN (EMPERICAL AREA REDUCTION METHOD DAN AREA INCREMENT METHOD)
}

\section{Study of Sedimentation Distribution in Bening Reservoir at Madiun District (Emperical Area Reduction Method dan Area Increment Method)}

\author{
Ernawan $^{1}$, Anastasia Irawati Putri ${ }^{2}$ \\ 1,2,3 Program Studi Teknik Sipil, Fakulas Teknik, Universitas Muhammadiyah Malang \\ Jalan Raya Tlogomas No. 246 Malang 65144 \\ Alamat Korespondensi: \\ Email: thieyadsg@gmail.com
}

\begin{abstract}
Bening reservoir is one of the reservoirs located in East Java province which has an area of $5,7 \mathrm{~km}^{2}$ area with water storage capacity of 31,7 million $\mathrm{m}^{3}$. In the management of a reservoir, there must be some problems among which is the problem of sedimentation. There are several methods that can be used to determine the distribution of sediments include Empirical methods Reduction Area, Area Incrament and Moody's Modification. In this study the method used is the method of Empirical methods Reduction Area and Area Incrament. From the analysis results obtained efficient method is the method of Empirical Area Reduction in order to get the volume of sediment that settles for 19 year amounted to 0,07million $\mathrm{m}^{3}$ and for 22 years 0,068 million $\mathrm{m}^{3}$.
\end{abstract}

Keywords : Sedimentation Distribution

\begin{abstract}
Abstrak
Waduk Bening merupakan salah satu waduk yang berada di Propinsi Jawa Timur yang memiliki luas daerah genangan sebesar $5,7 \mathrm{~km}^{2}$ dengan kapasitas tampungan air sebesar 31,7 juta $\mathrm{m}^{3}$. Dalam pengelolaan suatu waduk, pasti terdapat suatu masalah di antaranya yaitu masalah sedimentasi. Ada beberapa metode yang bisa digunakan untuk mengetahui distribusi sedimen diantaranya adalah metode Empirical Area Reduction, Area Incrament dan Moody's Modification. Pada studi kali ini metode yang digunakan adalah metode Empirical Area Reduction dan Area Incrament. Dengan bertujuan untuk mengetahui metode yang paling sesuai diantara Emperical Area Reduction Method dan Area Increment Method untuk memprediksi distribusi sedimen di Waduk Bening Madiun Jawa Timur. Dari hasil analisa didapat metode yang efisien yaitu metode Empirical Area Reduction sehingga didapat volume sedimen yang mengendap untuk 19 tahun sebesar 0,070 juta $\mathrm{m}^{3}$ dan untuk 22 tahun sebesar 0,068 juta $\mathrm{m}^{3}$.
\end{abstract}

Kata kunci : Distribusi Sedimen

\section{PENDAHULUAN}

Waduk merupakan suatu bangunan air yang berfungsi untuk menampung air yang digunakan pada saat debit rendah. Dari segi kegunaannya waduk ada dua yaitu, waduk eka guna misalnya waduk yang khusus digunakan untuk irigasi, pembangkit listrik, pengendalian banjir, dan waduk serba guna (multi purpose) misalnya waduk yang berguna menyeluruh dalam satu waduk itu.

Salah satu masalah dari waduk yaitu sedimentasi. Sedimentasi merupakan proses kelanjutan dari peristiwa erosi atau peristiwa terkikisnya permukaan tanah akibat air hujan. Tanah tesebut mengalir melalui cekungancekungan, saluran-saluran air, kemudian masuk ke sungai.
Dalam studi ini penulis ingin menganalisa distribusi sedimentasi dengan beberapa metode yaitu Moody's Modification, Empirical Area Reduction dan Area Increment. Dari tiga metode tersebut akan dibandingkan dan akan diambil metode yang memiliki simpangan yang terkecil untuk menganalisa distribusi sedimentasi untuk usia rencana.

\section{MetodeEmpirical AreaReduction .}

Metode ini dikemukakan oleh Whitney M. Borland dan Carl L. Miller (1960) yang kemudian diperbaiki oleh Lara pada tahun 1962. (Yang,1976) Langkah-langkah perhitungan distribusi sedimen di waduk adalah sebagai berikut : 
- Menetukan bentuk waduk yang sesuai

- Menghitung faktor tak berdimensi melalui persamaan berikut :

Dimana :

$$
\mathrm{F}=\frac{\mathrm{S}_{\mathrm{d}}-\mathrm{V}_{\mathrm{h}}}{\mathrm{H} \cdot \mathrm{A}_{\mathrm{h}}}
$$

$\mathrm{F}$ = faktor tanpa dimensi sebagai fungsi dari total endapan sedimen, kapasitas, kedalman dan luas waduk.

$\mathrm{Sd}=$ total endapan $\operatorname{sedimen}\left(\mathrm{m}^{3}\right)$.

$\mathrm{Vh}=$ kapasitas waduk pada elevasi $\mathrm{h}\left(\mathrm{m}^{3}\right)$.

$\mathrm{H}=$ kedalaman air waduk awal $(\mathrm{m})$.

$\mathrm{Ah}=$ luas waduk pada elevasi $\mathrm{h}\left(\mathrm{m}^{2}\right)$.

- Menghitung elevasi dari endapan sedimen yang mencapai bendungan yang merupakan titik dasar kedalaman baru (new zeroelevation) berdasarkan hasil perpotongan antara garis yang terbentuk melalui hubungan titik-titik harga $\mathrm{F}$ dengan lengkung harga kedalaman relative (p) untuk tipe bentuk waduk yang sesuai (pada langkah 1) dengan menggunakan grafik pada Gambar 1.
- Menentukan luas sedimen relative (Ap) pada setiap kedalaman waduk yang diperoleh dari rumus sebagai berikut :

$$
\begin{array}{ll}
\text { Tipe I } & : A p=5,074 \mathrm{P}^{1,85}(1-\mathrm{P})^{0,35} \\
\text { Tipe II } & : A p=2,487 \mathrm{P}^{0,57}(1-\mathrm{P})^{0,41} \\
\text { Tipe III } & : A p=16,967 \mathrm{P}^{1,15}(1-\mathrm{P})^{2,32} \\
\text { Tipe IV } & : A p=1,486 \mathrm{P}^{-0,25}(1-\mathrm{P})^{1,34}
\end{array}
$$

\section{Dimana :}

Ap = luas sedimen relative

$\mathrm{P} \quad=$ kedalaman waduk relative

diukur dari dasar

- Menghitung luas sedimen pada setiap elevasi waduk yang diperoleh dari harga Ap pada elevasi yang bersangkutan dikalikan denganharga Z. Harga $Z$ diperoleh dari luas mulamula waduk pada new zero elevation dibagi dengan harga Ap pada elevasi tersebut.

- Menghitung volume sedimen pada setiap elevasi waduk setelah luas sedimen diketahui.

$\mathrm{V}=\left\{\frac{(\text { Luas sedimen elevasi } \mathrm{n}-1)+(\text { Luas sedimen elevasi yang dituju })}{2} \times\right.$ selisih $\mathrm{H}$ antara elevasi $\}$

+ Volume sedimen elevasi n-1

- Berdasarkan perhitungan distribusi sedimen di Waduk Wonorejo tersebut, apabila volume sedimen kumulatif tidak sama dengan volume sedimen terendap, maka harga $\mathrm{Z}$ dikoreksi sebagai berikut:

$$
\mathrm{Z}_{2}=\mathrm{Z}_{1} \frac{\text { Jumlah sedimen kumulatif }}{\text { Jumlah sedimen yang terendap }}
$$

Harga Z dikoreksi terus sampai mendekati hasil jumlah sedimen yang terendapkan sama dengan sedimen kumulatif.

\section{Metode Area Increment}

- Menentukan kedalaman waduk, $\mathrm{h}_{\mathrm{o}}$ : Kedalaman waduk yang terisi sedimen di bawah elevasi dasar baru ditentukan dengan cara coba - coba (trial and eror).
- Menghitung Kedalaman waduk aktual, $\mathrm{H}: \mathrm{H}=$ elevasi $\mathrm{n}-\mathrm{LWL}$

- Menentukan luas terkoreksi, $\mathrm{A}_{\mathrm{o}}$ : Luas terkoreksi merupakan luasan pada kondisi awal pada elevasi $h$

- Menghitung sedimen total, Vs' :

Volume sedimen total yang terendap di waduk diperoleh berdasarkan persamaan sebagai berikut:

$\mathrm{Vs} \mathrm{s}^{\prime}=\mathrm{A}_{\mathrm{o}}\left(\mathrm{H}-\mathrm{h}_{\mathrm{o}}\right)+\mathrm{V}_{\mathrm{o}}$

Dimana :

$\mathrm{V}=$ volume sedimen $\left(\right.$ juta $\left.\mathrm{m}^{3}\right)$

$\mathrm{Ao}=$ luas sedimen (juta $\mathrm{m}^{2}$ )

$\mathrm{H}=$ kedalaman waduk $(\mathrm{m})$

yo $=$ pertambahan tinggi elevasi dasar (m)

ho = kedalaman waduk setelah terisi sedimen dibawah elevasi dasar waduk (m) 


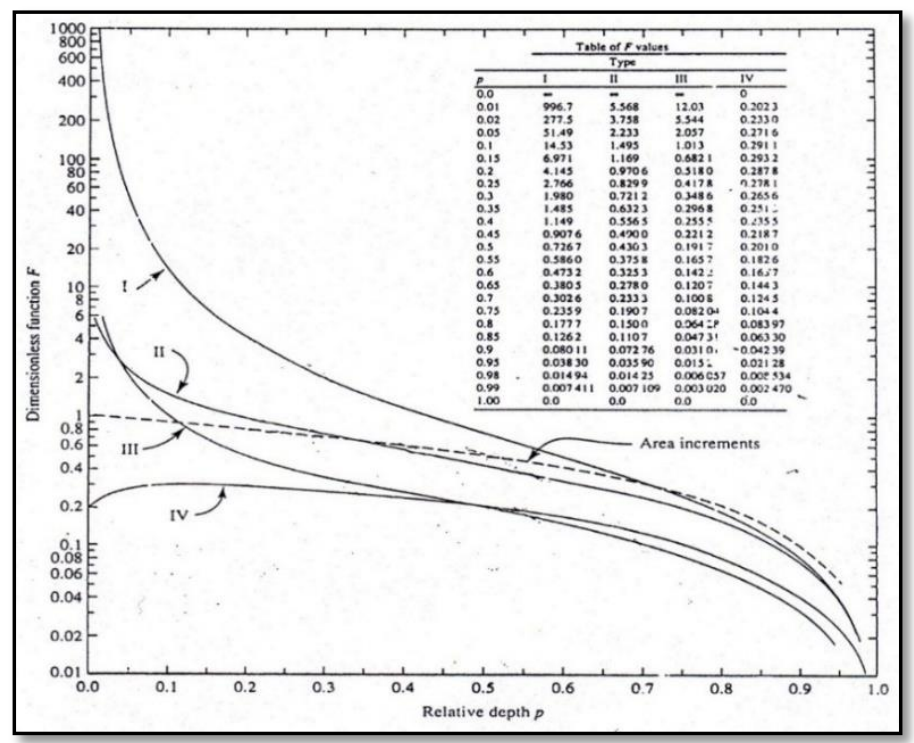

Gambar 1. Kurva Hubungan F - p

- Kontrol

$\mathrm{Vs}=\mathrm{Vs}$ ' atau selisih volume sedimen hasil perhitungan dengan volume sedimen awal tidak boleh lebih dari $1 \%$.

Penetuan metode yang cocok dengan kondisi yang sebenarnya didasarkan pada perhitungan simpangan mutlak yang terkecil antara data dengan hasil perhitungan, baik dari hasil perhitungan menggunakan

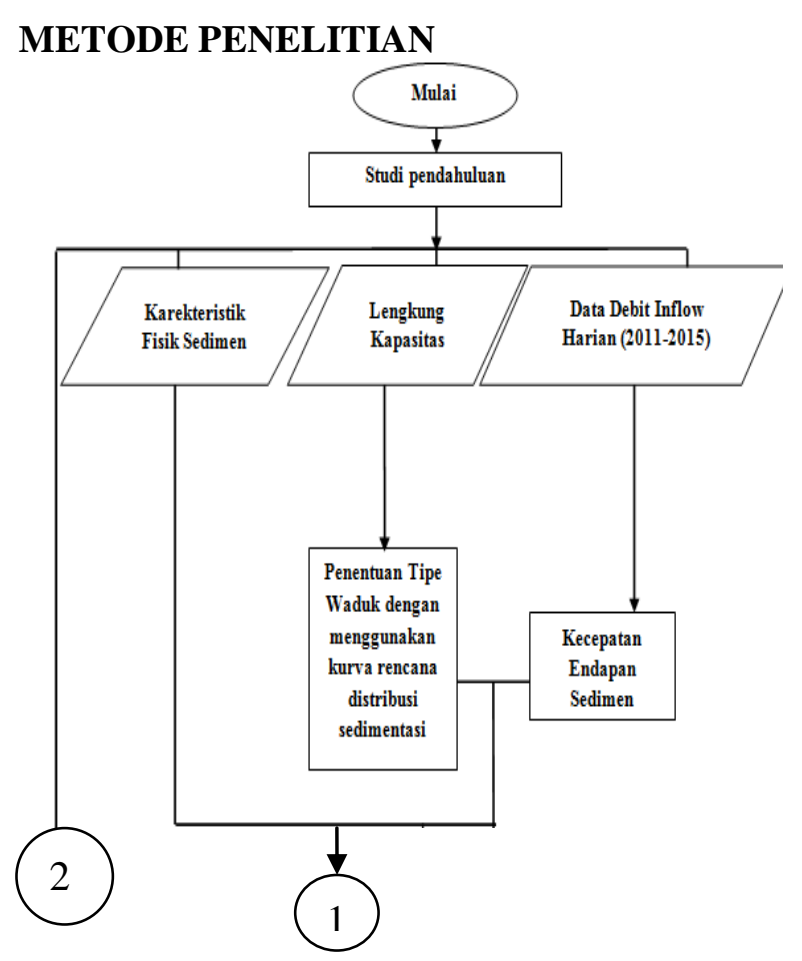

Empirical Area Reduction Method, Area Increment Method danMoody's Modification. Perhitungan simpangan mutlak menurut persamaan berikut :

$$
\mathrm{S}=\sum_{i=1}^{n}(\mathrm{Xi}-\mathrm{Xd})
$$

Dimana :

$\mathrm{n}$ = Jumlah Data

$\mathrm{Xi}=$ Kapasitas waduk hasil perhitungan

$\mathrm{Xd}=$ Kapasitas waduk hasil perhitungan echo sounding

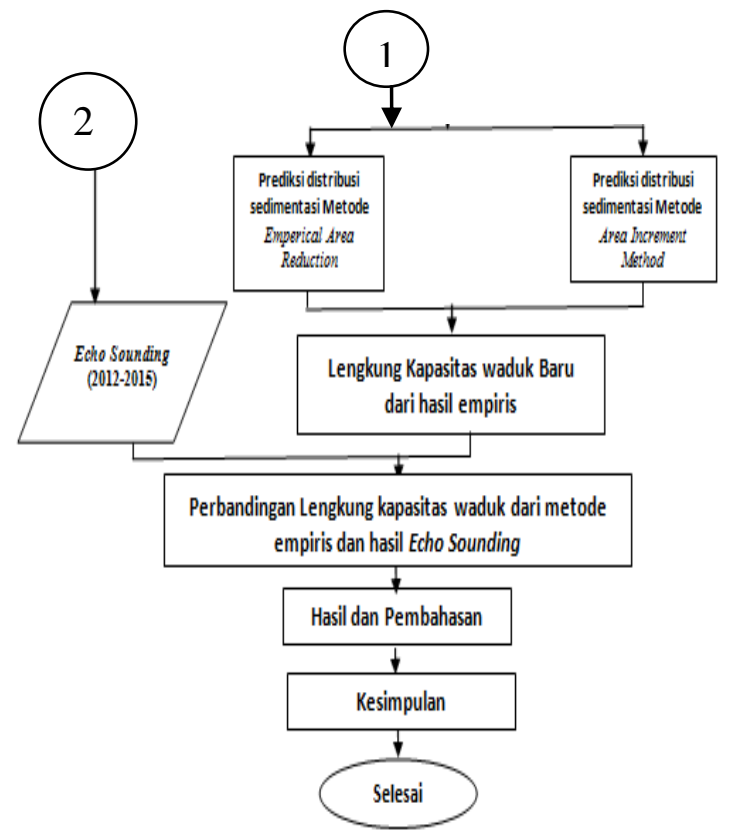

Gambar 2. Alur Kajian 
Tabel 1. Data Laju Sedimen Waduk Bening

\begin{tabular}{cccc}
\hline No. & Periode & Volume sedimen $\left(\mathrm{m}^{3}\right)$ & Rata-rata / Tahun $\left(\mathrm{m}^{3}\right)$ \\
\hline 1. & $1993-2012$ & $2.227 .543,90$ & $159.110,28$ \\
2. & $2012-2015$ & $2.977 .317,44$ & $595.463,49$ \\
\hline
\end{tabular}

Sumber : Perusahaan Umum (PERUM) Jasa Tirta 1

Tabel 2. Data Sedimen di Waduk Bening

\begin{tabular}{|c|c|c|c|c|c|c|}
\hline \multirow[t]{2}{*}{ Elevasi (m) } & \multicolumn{2}{|c|}{$\begin{array}{l}\text { Volume tampungan } \\
\left.\qquad \text { (juta } \mathrm{m}^{3}\right)\end{array}$} & \multirow{2}{*}{$\begin{array}{l}\text { Besar sedimen } \\
\quad\left(\text { juta } \mathrm{m}^{3}\right)\end{array}$} & \multicolumn{2}{|c|}{$\begin{array}{l}\text { Volume tampungan } \\
\qquad\left(\text { juta } \mathrm{m}^{3}\right)\end{array}$} & \multirow{2}{*}{$\begin{array}{l}\text { Besar sedimen } \\
\quad\left(\text { juta }^{3}\right)\end{array}$} \\
\hline & 1993 & 2012 & & 1993 & 2015 & \\
\hline HWL $=108,60$ & 31,704 & 28,634 & 2,97 & 31,704 & 28,634 & 2,97 \\
\hline $\mathrm{LWL}=90,4$ & 0,758 & 0,332 & 0,426 & 0,758 & 0,332 & 0,426 \\
\hline Volume Efektif & 30,946 & 28,302 & 2,544 & 30,946 & 28,302 & 2,544 \\
\hline
\end{tabular}

Sumber : Perusahaan Umum (PERUM) Jasa Tirta 1

\section{Data Debit Inflow}

Tabel 3. Data Debit Inflow Bulanan pada Tahun $2011-2015\left(\mathrm{~m}^{3} / \mathrm{det}\right)$

\begin{tabular}{cccccccccccccc}
\hline \multirow{2}{*}{ Tahun } & \multicolumn{11}{c}{ Bulan } \\
\cline { 2 - 12 } & Jan & Feb & Mar & Apr & May & Jun & Jul & Aug & Sep & Oct & Nov & Dec & \\
\hline 2011 & 1,955 & 2,118 & 2,104 & 3,451 & 3,061 & 0,53 & 0,586 & 0,286 & 0,201 & 0,088 & 2,453 & 1,692 & 18,525 \\
2012 & 3,138 & 1,976 & 0,591 & 1,506 & 0,268 & 0,362 & 0,099 & 0,36 & 0,073 & 0,101 & 0,231 & 1,496 & 10,201 \\
2013 & 2,342 & 3,222 & 3,108 & 3,422 & 1,553 & 1,476 & 0,524 & 0,159 & 0,223 & 0,298 & 0,578 & 3,278 & 20,183 \\
2014 & 1,626 & 2,5 & 2,922 & 1,755 & 0,202 & 0,22 & 0,256 & 0,101 & 0,13 & 0,117 & 0,422 & 2,59 & 12,841 \\
Jumlah & 10,693 & 14,53 & 13,74 & 14,207 & 5,084 & 2,588 & 1,465 & 0,906 & 0,627 & 0,604 & 3,684 & 9,056 & 77,186 \\
Rerata & 2,138 & 2,906 & 2,748 & 2,841 & 1,271 & 0,647 & 0,3662 & 0,226 & 0,1567 & 0,151 & 0,921 & 2,264 & 16,637 \\
\hline
\end{tabular}

Penentuan bentuk waduk dapat ditentukan dari kurva rencana distribusi sedimen yaitu kurva hubungan antara persentase sedimen yang mengendap dengan persentase kedalaman waduk menurut kedalaman pada awal rencana. Dengan menggunakan cara tersebut dapat diketahui bahwa Waduk Bening mendekati bentuk kurva tipe I. Kemudian menghitung kerapatan endapan sedimen, dengan terlebih dahulu menghitung kerapatan sedimen awal. Persentase butiran sedimen berupa pasir sebanyak 7,61\%, lanau sebanyak $65,78 \%$, lempung sebanyak $26,33 \%$.

Tabel 4. Kerapatan Endapan Sedimen

\begin{tabular}{cc}
\hline $\mathrm{T}$ (tahun) & $\mathrm{W}_{\mathrm{T}}\left(\right.$ ton $\left./ \mathrm{m}^{3}\right)$ \\
\hline 19 & 1,033 \\
22 & 1,037 \\
\hline \multicolumn{2}{c}{ Sumber $:$ hasil perhitungan }
\end{tabular}

Efisiensi tangkapan merupakan perbandingan antara jumlah endapan sedimen di waduk dengan totalsedimen yang masuk ke waduk. Jumlah sedimen yang tertahan di dalam waduk dapat diketahui dengan terlebih dahulu menentukan besarnya efisiensi tangkapan.

Tabel 5. Jumlah SedimenYang Tertahan Di Waduk Bening

\begin{tabular}{cccc}
\hline $\mathrm{T}$ & Wt & $\begin{array}{c}\text { Laju } \\
\text { Sedimen } \\
\left(10^{\wedge} \cdot \mathrm{m}^{3}\right)\end{array}$ & $\begin{array}{c}\text { Sedimen Yang } \\
\text { Mengendap } \\
\left(10^{6} \cdot \mathrm{m}^{3}\right)\end{array}$ \\
\hline 19 & 1,033 & 2,3028 & 28,801 \\
22 & 1,037 & 2,3101 & 31,345 \\
\hline \multicolumn{4}{l}{ Sumber : hasil perhitungan }
\end{tabular}

\section{HASIL DAN PEMBAHASAN}

Berikut adalah hasil analisa distribusi sedimen pada Waduk Bening menggunakan dua metode, yaitu: 


\section{Metode Empirical Area Reduction}

Tabel 6a. Distribusi Sedimen di Waduk Bening Untuk Masa Operasi Tahun 1993-2012

\begin{tabular}{ccccccccccc}
\hline & & \multicolumn{2}{c}{ Kondisi Tahun 1993 } & \multicolumn{2}{c}{ Relatif } & \multicolumn{2}{c}{ Sedimen } & \multicolumn{2}{c}{ Revised } \\
\cline { 3 - 10 } No & $\begin{array}{c}\text { Elevasi } \\
(\mathrm{m})\end{array}$ & $\begin{array}{c}\text { Luas } \\
\left(10^{\wedge} 6\right.\end{array}$ & $\begin{array}{c}\text { Kapasitas } \\
\left(10^{\wedge} 6\right.\end{array}$ & Kedalaman & Luas & Luas & Kapasitas & Luas & Kapasitas \\
& & $\left.\mathrm{m}^{\wedge} 2\right)$ & $\left.\mathrm{m}^{\wedge} 3\right)$ & $(\mathrm{p})$ & $($ Ap $)$ & $\begin{array}{c}\left(10^{\wedge} 6\right. \\
\left.\mathrm{m}^{\wedge} 2\right)\end{array}$ & $\begin{array}{c}\left(10^{\wedge} 6\right. \\
\left.\mathrm{m}^{\wedge} 3\right)\end{array}$ & $\begin{array}{c}\left(10^{\wedge} 6\right. \\
\left.\mathrm{m}^{\wedge} 2\right)\end{array}$ & $\begin{array}{c}\left(10^{\wedge} 6\right. \\
\left.\mathrm{m}^{\wedge} 3\right)\end{array}$ \\
\hline 1 & 108,6 & 0,21 & 31,74 & 1 & 0 & 0 & 0,07 & 0,21 & 31,67 \\
2 & 106,6 & 0,2 & 20,326 & 0,89 & 0,941 & 0,004 & 0,065 & 0,196 & 20,26 \\
3 & 104,5 & 0,2 & 14,636 & 0,775 & 1,167 & 0,005 & 0,057 & 0,195 & 14,57 \\
4 & 102,5 & 0,13 & 10,484 & 0,665 & 1,259 & 0,005 & 0,047 & 0,125 & 10,43 \\
5 & 100,5 & 0,1 & 7,519 & 0,555 & 1,267 & 0,005 & 0,037 & 0,095 & 7,48 \\
6 & 98,5 & 0,08 & 4,93 & 0,445 & 1,231 & 0,005 & 0,027 & 0,075 & 4,9 \\
7 & 96,5 & 0,05 & 3,652 & 0,335 & 1,128 & 0,004 & 0,018 & 0,046 & 3,63 \\
8 & 94 & 0,03 & 2,948 & 0,198 & 0,903 & 0,004 & 0,008 & 0,026 & 2,93 \\
9 & 92 & 0,02 & 1,434 & 0,088 & 0,599 & 0,002 & 0,002 & 0,018 & 1,432 \\
10 & 91,4 & 0,01 & 1,096 & 0,055 & 0,465 & 0,002 & 0,001 & 0,008 & 1,095 \\
11 & 91,3 & 0,01 & 1,086 & 0,049 & 0,437 & 0,002 & 0,001 & 0,01 & 1,085 \\
12 & 90,4 & 0 & 0 & 0 & 0 & 0 & 0 & 0 & 0 \\
\hline
\end{tabular}

Sumber : Hasil Perhitungan

Tabel 6b. Distribusi Sedimen di Waduk Bening Untuk Masa Operasi Tahun 2012-2015

\begin{tabular}{|c|c|c|c|c|c|c|c|c|c|}
\hline \multirow[b]{2}{*}{ No } & \multirow[b]{2}{*}{$\begin{array}{c}\text { Elevasi } \\
(\mathrm{m})\end{array}$} & \multicolumn{2}{|c|}{ Kondisi Tahun 1993} & \multicolumn{2}{|c|}{ Relatif } & \multicolumn{2}{|c|}{ Sedimen } & \multicolumn{2}{|c|}{ Revised } \\
\hline & & $\begin{array}{l}\text { Luas } \\
\left(10^{\wedge} 6\right. \\
\left.\mathrm{m}^{\wedge} 2\right)\end{array}$ & $\begin{array}{c}\text { Kapasitas } \\
\left(10^{\wedge} 6\right. \\
\left.\mathrm{m}^{\wedge} 3\right)\end{array}$ & $\begin{array}{c}\text { Kedalaman } \\
\text { (p) }\end{array}$ & $\begin{array}{l}\text { Luas } \\
\text { (Ap) }\end{array}$ & $\begin{array}{l}\text { Luas } \\
\left(10^{\wedge} 6\right. \\
\left.\mathrm{m}^{\wedge} 2\right)\end{array}$ & $\begin{array}{c}\text { Kapasitas } \\
\left(10^{\wedge} 6\right. \\
\left.m^{\wedge} 3\right)\end{array}$ & $\begin{array}{c}\text { Luas } \\
\left(10^{\wedge} 6\right. \\
\left.\mathrm{m}^{\wedge} 2\right)\end{array}$ & $\begin{array}{c}\text { Kapasitas } \\
\left(10^{\wedge} 6\right. \\
\left.m^{\wedge} 3\right)\end{array}$ \\
\hline 1 & 108,6 & 0,21 & 31,74 & 1 & 0 & 0 & 0,068 & 0,21 & 31,7 \\
\hline 2 & 106,6 & 0,2 & 20,326 & 0,89 & 0,941 & 0,0037 & 0,0652 & 0,2 & 20,3 \\
\hline 3 & 104,5 & 0,2 & 14,636 & 0,775 & 1,167 & 0,0046 & 0,0565 & 0,2 & 14,6 \\
\hline 4 & 102,5 & 0,13 & 10,484 & 0,665 & 1,259 & 0,0049 & 0,047 & 0,13 & 10,4 \\
\hline 5 & 100,5 & 0,1 & 7,519 & 0,555 & 1,276 & 0,005 & 0,0371 & 0,1 & 7,5 \\
\hline 6 & 98,5 & 0,08 & 4,93 & 0,445 & 1,231 & 0,0048 & 0,0273 & 0,08 & 4,9 \\
\hline 7 & 96,5 & 0,05 & 3,652 & 0,335 & 1,128 & 0,0044 & 0,0181 & 0,05 & 3,6 \\
\hline 8 & 94 & 0,03 & 2,948 & 0,198 & 0,902 & 0,0035 & 0,0082 & 0,03 & 2,9 \\
\hline 9 & 92 & 0,02 & 1,434 & 0,088 & 0,599 & 0,0023 & 0,0023 & 0,02 & 1,4 \\
\hline 10 & 91,4 & 0,01 & 1,096 & 0,055 & 0,465 & 0,0018 & 0,0011 & 0,01 & 1,1 \\
\hline 11 & 90,95 & 0,004 & 0,348 & 0,03 & 0,334 & 0,0013 & 0,0004 & 0 & 0,3 \\
\hline 12 & 90,4 & 0 & 0 & 0 & 0 & 0 & 0 & 0 & 0 \\
\hline
\end{tabular}

Sumber : Hasil Perhitungan 


\section{Metode Area Increment}

Tabel 7a. Distribusi Sedimen di Waduk Bening Untuk Masa Operasi Tahun 1993-2012

\begin{tabular}{|c|c|c|c|c|c|c|c|c|}
\hline \multirow{3}{*}{ No } & \multirow{3}{*}{$\begin{array}{c}\text { Elevasi } \\
\text { (m) }\end{array}$} & \multicolumn{2}{|c|}{ Kondisi Tahun 1993} & \multirow{3}{*}{$\mathrm{H}(\mathrm{m})$} & \multirow{3}{*}{$\begin{array}{c}\text { Ao } \\
\left(10^{\wedge} 6\right. \\
\left.\mathrm{m}^{\wedge} 2\right)\end{array}$} & \multirow{3}{*}{$\begin{array}{c}\mathrm{Vs}^{\prime} \\
\left(10^{\wedge} 6\right. \\
\left.\mathrm{m}^{\wedge} 3\right)\end{array}$} & \multicolumn{2}{|c|}{ Revised } \\
\hline & & Luas & Kapasitas & & & & luas & Kapasitas \\
\hline & & $\begin{array}{l}\left(10^{\wedge} 6\right. \\
\left.m^{\wedge} 2\right)\end{array}$ & $\left(10^{\wedge} 6 \mathrm{~m}^{\wedge} 3\right)$ & & & & $\left(10^{\wedge} 6 \mathrm{~m}^{\wedge} 2\right)$ & $\left(10^{\wedge} 6 \mathrm{~m}^{\wedge} 3\right)$ \\
\hline 1 & 108,6 & 0,21 & 31,74 & 18,2 & 0,03 & 3,176 & 0,18 & 28,56 \\
\hline 2 & 106,6 & 0,2 & 20,326 & 16,2 & 0,03 & 3,116 & 0,17 & 17,21 \\
\hline 3 & 104,5 & 0,2 & 14,636 & 14,1 & 0,03 & 3,053 & 0,17 & 11,58 \\
\hline 4 & 102,5 & 0,13 & 10,484 & 12,1 & 0,03 & 2,993 & 0,1 & 7,49 \\
\hline 5 & 100,5 & 0,1 & 7,519 & 10,1 & 0,03 & 2,933 & 0,07 & 4,59 \\
\hline 6 & 98,5 & 0,08 & 4,93 & 8,1 & 0,03 & 2,873 & 0,05 & 2,06 \\
\hline 7 & 96,5 & 0,05 & 3,652 & 6,1 & 0,03 & 2,813 & 0,02 & 0,84 \\
\hline 8 & 94 & 0,03 & 2,948 & 3,6 & 0,03 & 2,735 & 0 & 0 \\
\hline 9 & 93,9 & 0,03 & 2,735 & 3,5 & 0,03 & 2,735 & 0 & 0 \\
\hline 10 & 92 & 0,02 & 1,434 & 1,6 & 0,02 & 1,434 & 0 & 0 \\
\hline 11 & 91,4 & 0,01 & 1,096 & 1 & 0,01 & 1,096 & 0 & 0 \\
\hline 12 & 90,4 & 0 & 0 & 0 & 0 & 0 & 0 & 0 \\
\hline
\end{tabular}

Sumber : Hasil Perhitungan

Tabel 7b. Distribusi Sedimen di Waduk Bening Untuk Masa Operasi Tahun 2012-2015

\begin{tabular}{|c|c|c|c|c|c|c|c|c|}
\hline \multirow[b]{2}{*}{ No } & \multirow[b]{2}{*}{$\begin{array}{c}\text { Elevasi } \\
(\mathrm{m})\end{array}$} & \multicolumn{2}{|c|}{ Kondisi Tahun 1993} & \multirow[b]{2}{*}{$\mathrm{H}(\mathrm{m})$} & \multirow{2}{*}{$\begin{array}{c}\text { Ao } \\
\left(10^{\wedge} 6\right. \\
\left.\mathrm{m}^{\wedge} 2\right)\end{array}$} & \multirow{2}{*}{$\begin{array}{c}\mathrm{Vs}^{\prime} \\
\left(10^{\wedge} 6\right. \\
\left.\mathrm{m}^{\wedge} 3\right)\end{array}$} & \multicolumn{2}{|c|}{ Revised } \\
\hline & & $\begin{array}{l}\text { Luas } \\
\left(10^{\wedge} 6\right. \\
\left.\mathrm{m}^{\wedge} 2\right) \\
\end{array}$ & $\begin{array}{l}\text { Kapasitas } \\
\left(10^{\wedge} 6 \mathrm{~m}^{\wedge} 3\right)\end{array}$ & & & & $\begin{array}{c}\text { Luas } \\
\left(10^{\wedge} 6 \mathrm{~m}^{\wedge} 2\right)\end{array}$ & $\begin{array}{l}\text { Kapasitas } \\
\left(10^{\wedge} 6 \mathrm{~m}^{\wedge} 3\right)\end{array}$ \\
\hline 1 & 108,6 & 0,21 & 31,74 & 18,2 & 0,021 & 2,857 & 0,19 & 28,88 \\
\hline 2 & 106,6 & 0,2 & 20,326 & 16,2 & 0,021 & 2,815 & 0,18 & 17,51 \\
\hline 3 & 104,5 & 0,2 & 14,636 & 14,1 & 0,021 & 2,771 & 0,18 & 11,87 \\
\hline 4 & 102,5 & 0,13 & 10,484 & 12,1 & 0,021 & 2,729 & 0,11 & 7,76 \\
\hline 5 & 100,5 & 0,1 & 7,519 & 10,1 & 0,021 & 2,687 & 0,08 & 4,83 \\
\hline 6 & 98,5 & 0,08 & 4,93 & 8,1 & 0,021 & 2,645 & 0,06 & 2,29 \\
\hline 7 & 96,5 & 0,05 & 3,652 & 6,1 & 0,021 & 2,603 & 0,03 & 1,05 \\
\hline 8 & 94 & 0,03 & 2,948 & 3,6 & 0,021 & 2,55 & 0 & 0,4 \\
\hline 9 & 92,9 & 0,021 & 2,527 & 3,5 & 0,021 & 2,527 & 0 & 0 \\
\hline 10 & 92 & 0,02 & 1,434 & 1,6 & 0,02 & 1,434 & 0 & 0 \\
\hline 11 & 91,4 & 0,01 & 1,096 & 1 & 0,01 & 1,096 & 0 & 0 \\
\hline 12 & 90,4 & 0 & 0 & 0 & 0 & 0 & 0 & 0 \\
\hline
\end{tabular}

Sumber : Hasil Perhitungan

Dari hasil analisa tiga metode tersebut maka didapat perbandingan lengkung kapasitas sebagai berikut: 


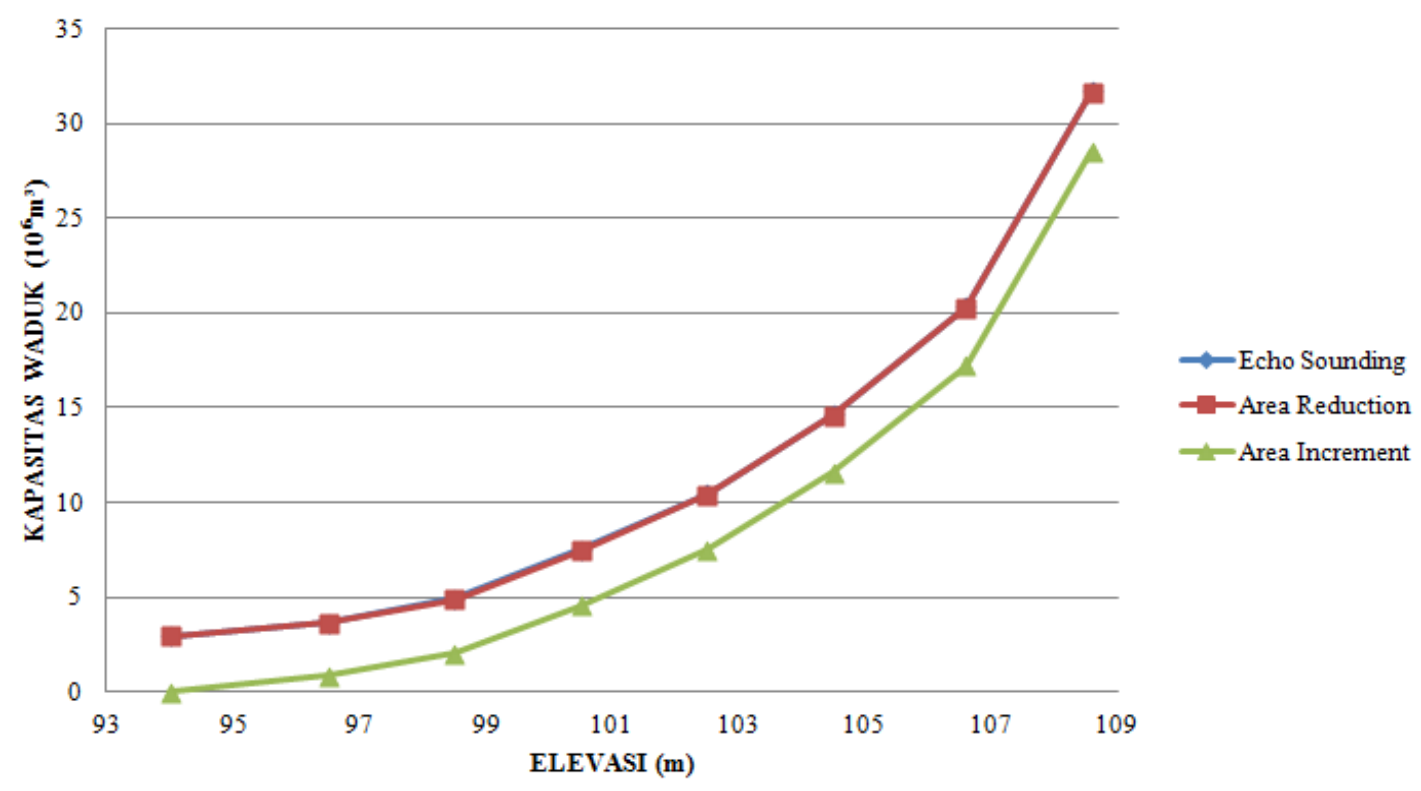

Gambar 3. Perbandingan Lengkung Kapasitas Waduk tahun 2012

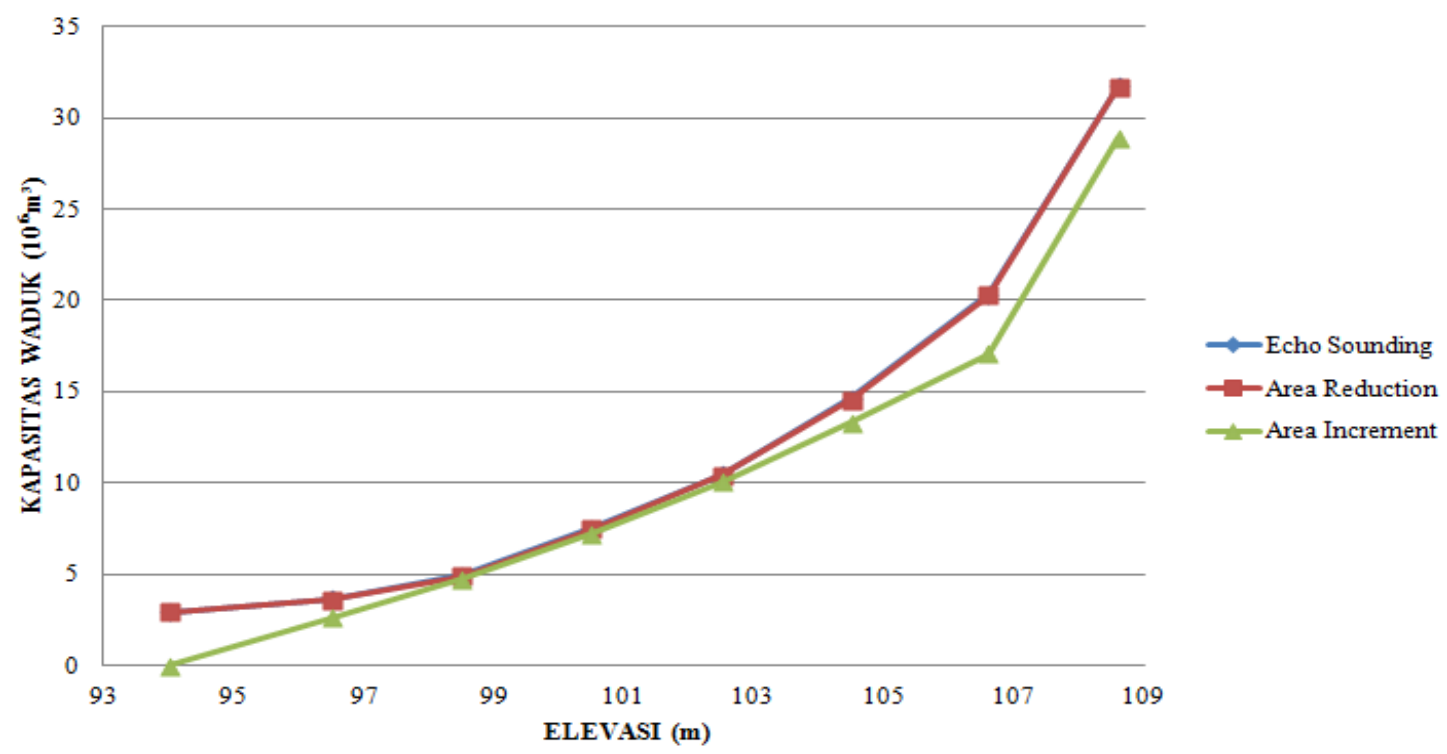

Gambar 4. Perbandingan Lengkung Kapasitas Waduk tahun 2015

Tabel 8. Besarnya Simpangan Pada Kedua

\begin{tabular}{ccc}
\multicolumn{2}{c}{ Metode } \\
\hline \multirow{3}{*}{ Mahun } & \multicolumn{2}{c}{ Metode } \\
\cline { 2 - 3 } & Area & Area \\
& Reduction & Increment \\
2012 & $\left(10^{6} \mathrm{~m}^{3}\right)$ & $\left(10^{6} \mathrm{~m}^{3}\right)$ \\
2015 & 0,328 & 23,692 \\
& 0,327 & 21,655 \\
\hline
\end{tabular}

Sumber : Hasil Perhitungan

Berdasarkan tabel diatas, Metode Area Reduction memiliki simpangan lebih kecil dibandingkandengan Metode Area Increment.

\section{KESIMPULAN DAN SARAN \\ Kesimpulan}

- Volume sedimen di Waduk Bening adalah sebagai berikut :

- Emprical Area Reduction Method

Untuk Masa Operasi tahun 19932012 sebesar 0,069 juta $\mathrm{m}^{3}$ dan untuk masa operasi tahun 2012-2015 sebesar 0,065 juta $\mathrm{m}^{3}$

- Area Increment Method

Untuk Masa Operasi tahun 19932012 sebesar 3,176 juta $\mathrm{m}^{3}$ dan untuk masa 
operasi tahun 2012-2015 sebesar 2,857 juta $^{3}$

- Elevasi dasar waduk baru(new zero elevation)adalah sebagai berikut :

- Emprical Area Reduction Method

Untuk Masa Operasi 19 tahun elevasi $+91,31$ dan untuk masa operasi 22 tahun elevasi $+96,95$

- Area Increment Method Untuk Masa Operasi 19 tahun elevasi $+93,90$ dan untuk masa operasi 22 tahun elevasi $+92,90$

- Metode yang paling sesuai untuk memprediksi distribusi sedimentasi di Waduk Bening adalah Emprical Area Reduction Method, karena memiliki simpangan lebih kecil dibandingkan dengan Area Increment Method, baik pada tahun 2012 maupun tahun 2015.

\section{Saran}

- Perlu dilakukan studi lebih lanjut mengenai penyebab besarnya laju sedimentasi di Waduk Bening serta penangananya.

- Mengingat tingkat laju sedimentasi rata-rata pertahun cukup tinggi, maka perlu dilakukan monitoring sedimentasi secara periodik sekurang-kurangnya 5 tahun sekali.
- Perlu dilakukan usaha-usaha pencengahan sedimentasi ke Waduk Bening mengingat pentingnya Waduk Bening bagi masyarakat Kabupaten Madiun.

\section{DAFTAR PUSTAKA}

Priyantoro, Dwi. 1987. Teknik Pengukuran Sedimen. Malang: Teknik Universitas Brawijaya

Soemarto, CD. 1987. Hidrologi Teknik. Surabaya : Penerbit Usaha Nasional

Soewarno, 2015. Analisis Data Hidrologi Menggunakan Metode Statistika dan Stokastik. Yogyakarta : Graha Ilmu

Yang, Chih Ted. 1976. Sedimen TranspoertasiNew York : Mc Graw Hill Compaines, Inc

Faris, Rahman. 2015. Studi Kajian Distribusi Sedimentasi Waduk Sutami - Karangkates Malang-Jawa Timur (Tahun 2009-2013). Skripsi Tidak Diterbitkan, Jurusan Teknik Sipil, Universitas Muhammadiyah Malang

Perusahaan Umum (PERUM) Jasa Tirta 1. 2011-2015.Debit Inflow. Tidak dipublikasikan. Malang: Perusahaan Umum (PERUM) Jasa Tirta 1.

Perusahaan Umum (PERUM) Jasa Tirta 1. 2012-2015. Echo Sounding. Tidak dipublikasikan.Malang: Perusahaan Umum (PERUM) Jasa Tirta 1. 